\title{
CRITICAL STUDY TO THE ENFORCEABILITY OF PASSIVE NATIONAL PRINCIPLE IN INDONESIA CRIMINAL CODE ${ }^{\Omega}$
}

\author{
Ridwan \\ Law Faculty of Sultan Ageng Tirtayasa University \\ E-mail: ridwan_untirta@yahoo.co.id
}

\begin{abstract}
Criminal law is law formulation to protect society and to establish society welfare as its address. Protection was, according criminal law, naturally as a concept of Human Rights protection. Based on those, therefore criminal law was implemented certainty, equality and expediency principle. But then, those law principles or basic values, seem difficult to improve by Indonesian citizen abroad, specifically Indonesian workers facing the law. Yet, according to limited-National Passive Principle in specific interest, and not including all Indonesian citizens abroad. It will cause unbalancing doelmatigheid ND rechtsmatigheid Principles not improving.
\end{abstract}

Key words: human rights protection, national passive principle, law enforcement, criminal law

\begin{abstract}
Abstrak
Hukum pidana, merupakan sebuah rumusan hukum yang memiliki tujuan yakni upaya perlindungan masyarakat dan upaya mencapai kesejahteraan masyarakat. Perlindungan yang terkandung dalam hukum pidana tersebut, pada hakikatnya merupakan konsep yang terkandung dalam negara hukum, yang di dalamnya termuat ketentuan perlindungan Hak Asasi Manusia. Mendasarkan pada konsep negara hukum dan peranan utama hukum itulah kemudian hukum pidana telah menjalankan prinsip kepastian hukum, keadilan dan kemanfaatan. Namun demikian, prinsip atau nilai dasar hukum tersebut, tampaknya sangat sulit diwujudkan bagi warga negara Indonesia yang berada di luar negeri, khususnya bagi para tenaga kerja Indonesia yang tengah berhadapan dengan hukum. Hal ini disebabkan oleh asas nasional pasif yang terbatas hanya pada kepentingan tertentu, dan tidak mencakup kepentingan seluruh warga Negara yang berada di luar negeri. Hal ini juga mengakibatkan tidak terwujudnya keseimbangan prinsip doelmatigheid dan rechtsmatigheid.
\end{abstract}

Kata kunci: perlindungan hak asas manusia, prinsip nasional pasif, penegakan hukum, hukum pidana

\section{Preface}

Criminal law is not just a law formulation without a purpose. Criminal law has a substantial purpose for nation, country, and society. Barda Nawawi Arief, said that the essential of crime prevention is integral part of social defense and social welfare. ${ }^{1}$ Two protection concepts that be contained in criminal law, is also the concept of state law, whereas according to Solihin that the concept of state law is covering social welfare, also moving toward to publish hu-

$\Omega$ This article is the result of research conducted by letter of assigment from Dean of Law Faculty, Sultan Ageng Tirtayasa Univesity, No. 710/UN43.1/TU/2014, Juni $13^{\text {th }}$, 2014

1 Barda Nawawi Arief, 2008, Bunga Rampai Kebijakan Hukum Pidana, Perkembangan Penyusunan Konsep KUHP Baru, Jakarta: Kencana, page 2. man rights protection in the written constitution. Besides, be on charge in social welfare and social justice, a state should give human rights protection. ${ }^{2}$ Actually, the concept of law state is directly proportional to the main role of law, Soerjono Soekanto said that law has 3 main roles, which are: as social control, as medium to expedite social interaction, as medium to create certain condition. ${ }^{3}$ Based on the concept of state law and main roles of law, criminal law has run principle of law supremacy, justice and expe-

2 Sodikin, "Dinamika Politik Hukum Hak Asasi Manusia", Jurnal Konstitusi PKK, Vol. II No. 1 June 2011, Lombok: UNRAM Law Faculty, page 104.

3 Adi Hemansyah, "Penanggulngan Kejahatan dengan Pidana Badan di Indonesia," Jurnal Kanun, Vol. XV No. 60 August Edition 2013, Banda Aceh: Law Faculty of Syiah Kuala University, page 183. 
diency, according to Radbruch, those 3 concepts is the basic value of law. ${ }^{4}$ The basic value of law is difficult to be applied for Indonesian citizens in foreign country, especially for Indonesia labor who on case.

An example that shows how hard to apply The basic value of law for Indonesian citizen in foreign country, especially Indonesia labor. First, Sukarno's case, Indonesian Labor in Malaysia from Kulonprogo who died because stabbed by stranger in Selangor Malaysia. ${ }^{5}$ Second, Kartika Puspitasari, Indonesian Labor in Hongkong who tortured by her employer. ${ }^{6}$ Third, rape case that experienced by several Indonesia labor in Malaysia Problem solving on that case, often issue problem, particularly on justice side which far away from reality, so the existence of Indonesia penal code is not able to solve the conflict. Whereas, according to Hulsman and G. Peter, law is medium to solve the conflict rationally, because it doesn't posit on strengtheners and weakness naturally but, also based on objective criteria. Law order is an objective interest of all parties in society. ${ }^{7}$ Those experts thought lead to clear and firm way that criminal law is focusing on the balance of doelmatigheid and rechtsmatigheid principle. Jimly Asshidiqie argued that, to reach or to find the balance of doelmatigheid and rechtsmatigheid principle, apart from subject factor that involve, it is environment factor that has effect on deciding right and fair decision. Include it, space and time that has great impact on that. Space is like ke-indonesian space, primordial space, location space, or trial space. $^{8}$

Regarding with the balance of doelmatigheid and rechtsmatigheid principle, criminal law will be believed has benefit for people, no exception Indonesia citizen in foreign country. If

4 Ridwan, "Menelaah Kembali Penerapan hukum Represif dalam Penegakan Hukum Pidana di Indonesia", Jurnal Litigasi, Vol. 10 No. 2 June 2009, Bandung: Law Faculty of UNPAS, page 223.

5 BNP2TKI, $17^{\text {th }}$ of June 2010, TKI Kulon Progo Jadi Korban Kejahatan di Selangor, available at website http://www. bnp2tki.go.id/berita-mainmenu-231/2572-tki-kulonprogo-jadi-korban-kejahatan-di-selangor.html, accessed on $4^{\text {th }}$ August 2014

6 Fera nuraini, 27 $7^{\text {th }}$ of May 2014, Kartika Ajukan Banding Kasus Penyiksaannya, Migrant Workers Resource Center, available at website http://www.buruhmigran.or.id/ the principle of criminal law, such as explanation above can be applied, there will be no case that Indonesia citizen involved in. Criminal law doesn't take side on Indonesia labor who deal with case. Ironically, not all of them commit crime intentionally even they are victim.

\section{Research Problems}

Based on the explanation above, there are 2 main ideas which are: first, how Indonesia criminal law give protection to Indonesian citizen?; and second, is the passive national principle can protect Indonesian citizen in foreign country?

\section{Research Methods}

This research use juridical-normatif method, with comparative approach. Juridical method is used to know how far application of law principle, vertical/horizontal synchronization, and law system, based on secondary data. Secondary data that used in this research is a collection from primary source, which is law. Comparative approach is used to supportive agent and to compare the formulation of passive national principle in other country, which is France. Therefore, it use policy-oriented approach.

\section{Result and Discussion \\ Penal Code Protection for Every Citizen of Indonesia}

Law in general, including criminal law has a purpose to protect people from arbitrariness, Peters said, as quoted by Barda Nawawi Arief, that restriction and controlling/supervising of state power is juridical dimension of criminal law; juridical role of criminal law is not to "set

2014/05/27/kartika-ajukan-banding-kasuspenyiksaannya/, accessed on $4^{\text {th }}$ August 2014.

7 Langgeng Purnomo, “Kesepakatan Sosial sebagai Upaya Pencegahan dan Penanggulangan Tindak Pidana Pemilu (studi Kasus Konflik Pemilu Tahun 2004 di Kabupaten Batang)", Jurnal Pembaharuan Hukum, Vol. 3 No.1 February 2007, Semarang: Program Magister Ilmu Hukum Pasca Sarjana UNDIP, page 12.

8 Jimly Asshidiqie, “Judicial Review, Kajian Atas Putusan Permohonn Hak Uji Materil Terhadap PP.No.19 Tahun 2000 TentangTGPTPK", Jurnal Dictum, Edisi 1, 2002, Jakarta : LelP, page 51. 
society" but to "set the ruler". ${ }^{9}$ This restriction is so important, in order to protect society, as Wagiati Soetedjo said that everyone is risky to become victim of criminal law, and everyone who become victim should get attention, effective and special treatment. ${ }^{10}$ According to Yusrizal, an incident always end up with suffer and disadvantage for victim, the impact is depend on the incident. ${ }^{11}$

Everybody is at risk of being victim with different suffering (depend on the incident that follow up), therefore the government should understand it from all point of view, so there will be no mistake whether they are victim or suspect, as Rudi Hartono said if there is a crime, there is a victim. ${ }^{12}$ This concern will bring effective treatment to them, whether they are victim or suspect.

The characteristic of relative theory on criminal law is the effectiveness of treating victim or suspect. According to Mohd. Dini, this theory seeks justify outside doing an injustice, in order to achieve the purpose with criminal path and criminal pursuit. Criminal law is given so that there is no crime (ne peccetur). ${ }^{13}$ According to Muladi and Barda Nawari Arief this theory as a protection towards society, based on this theory convict is not to please absolute lawsuits from justice. Retaliation is nothing except to protect society interest. ${ }^{14}$ Based on that, criminal law has a great purpose, which is to protect people so there will be law supremacy. If everyone can sense of justice, it means that criminal law has benefit. Therefore, role of the state be required because juridically state has obligation to protect its citizen from crime, whether as a

Ridwan, “Upaya Penanggulangan Terorisme yang Berkarakter Hak Asasi Manusia di Indonesia”, Jurnal Media Hukum, Vol. 17 No. 1 June 2010, Yogyakarta: Law Faculty of UMY, page 180 .

10 Wagiati Soetedjo, "Perlindungan Hukum Terhadap Anak dalam Hukum Pidana di Indoneia”, Jurnal Litigasi, Vol. 10 No. 2 June 2009, Bandung: Law Faculty of UNPAS, page 183.

11 Yusrizal, “Tanggung Jawab Korporasi Terhadap Korban Kejahatan Tindak Pidana Lingkungan Hidup", Kanun Journal, Vol. XIV No. 57 August Edition 2012, Banda Aceh: Law Faculty of Syiah Kuala University, page 229.

12 Aliyt Prakarsa, "Tanggung Jawab Dunia Akademik dalam Upaya Perlindungan Korban”, Jurnal Jure Humano, Vol. 1 No. 1 March 2009, Serang: Law Faculty of Sultan Ageng Tirtayasa University, page 12. victim or suspect. In extended view, protection not only for Indonesia citizen in Indonesia but also in foreign country.

\section{Passive National Principle Implementation of Criminal Code in Indonesia}

One of the effort to protect Indonesia citizens is through realignment the criminal law which is outmoded. Related with it, Barda Nawawi Arief affirmed that in all of united nations congress which held once in five years about "the prevention of Crime and the Treatment of Offenders", stated that criminal law in several contries (from colonial law) usually "obsolete and ujust" and "outmoded and unreal". ${ }^{15}$

In the interest of protecting nation, there must be criminal law reform. Criminal law reform is based on the law derived from cultural values, so it will be primary social institution. The application of law as primary social institution should not be a problem for Indonesia citizen because of the significance development where the organizing of society is on modern age and the deviation can be avoided.

Indonesia as a state, must show off sophisticated culture, so once again "principle or basic value of law" can be applied without obstacles, since according to Johanes Andreas that the functionary of criminal law is based on cultural context. Law and other factors that influence human behaviour has a reciprocal relationship. ${ }^{16}$ Based on it, inevitably that law and culture is related. The reform of criminal based on Indonesia cultural value is important, in order to reduce discrepancy toward nation, and to avoid mistakes in law substance that will be applied, on this

13 Mohd. Din, "Restoratif Justice dalam Wawasan Pemidanaan Menurut Hukum aAdat Gayo", Jurnal Kanun, Vol. IIX No. 50 April 2010, Banda Aceh : Law Faculty of Syiah Kuala University, page 71.

14 Ridwan, "Meneropong Efektifitas Sistem Pemidanaan di Indonesia", Jurnal Jure Humano, Vol. 3 No. 6 April 2012, Serang: Law Faculty of Sultan Ageng Tirtayasa University, page 44

15 Ridwan, "Kajian Perbandingan dalam Rangka Pembaharuan Hukum Pidana Indonesia" Jure Humano Journal, Vol. 2 No. 3 No. 4 July 2010, Serang: Law Faculty of Sultan Ageng Tirtayasa University, page 49.

16 Ridwan, "Relevansi, Restorative Justice dalam Penanganan Anak Delinquen" Jurnal Jure Humano, , Vol. 1 No. 3 November 2009, Serang: Law Faculty of Sultan Ageng Tirtayasa University, page 67. 
case Barda Nawawi Arief said that the formation of creating law is a process of law enforcement in abstaracto". The formulation process is a strategist early stage of law enforcement "in concreto". Mistake/weakness in the formulation policy stage is a big mistakes which can obstruct law enforcement "in concreto". ${ }^{17}$

Therefore, the reform of law based on cultural values is a must. The context of law reform according to Barda Nawawi Arief, means that: first, It's part of policy (rational effort) to renew the substance of law (legal substance) in order to create more effectiveness of law enforcement; second, It's part of policy (rational effort) combat crime in order to protect society; third, It's part of policy (rational effort) to solve social and humanitarian problems in order to support national goals ("social defense" and "social welfare"). It's effort to review and assessment main ideas, basic ideas, or values sociophilosphy, sociopolitical, and sociocultural that underlying criminal policy and criminal law enforcement policy. It could not called as reform criminal law if the value of orientation criminal law that aspired is same as the value orientation of the old criminal law colonial heritage. ${ }^{18}$

The law enforcement as the rational effort, is impossible can be succeed without involving human. Satjipto Rahardjo said wisely, that the law enforcement always involving human inside of it and also involving human's behavior. The law cannot stand itself, it means the law have no capability to realize their own promises and willingness in the rule of law. That promises and willingness, for example to give the right of people, give protection, determined criminal on someone who fulfill certain requirements and so on. ${ }^{19}$

It can be understood that law enforcement, whether in application or process should involving human and human's behavior, because

17 Ridwan, "Kebijakan Formulasi Hukum Pidana dalam Penanggulangan Tindak Pidana Korupsi", Jurnal Kanun, Vol. XV, No. 60 August 2013, Banda Aceh: Law Faculty of Syiah Kuala University, page 203

18 Ibid. page115.

19 Ridwan, "Upaya Memperbaharui sistem Hukum Guna Membangun Integritas Penegak Hukum”, Jurnal Konstitusi PKK, Vol. II No. 1 June Edition 2011, Lombok: Law Faculty of UNRAM, page 35 . law that included criminal law is the part of psychological science which include about consciousness. Barda Nawawi Arief said, that aspects of this spiritual value and attached to any law in general. So, it's usual if law (included law of crime is grouped into spiritual science ("geisteswissenschaft"). ${ }^{20}$

A cultivation of criminal law must be always considering psychological aspect, because behavior should be regulated, is a psychological reflection, and give attention to psychological aspect in behavior that should be regulated, will easily lead to protection to people as individual or society. Based on that consideration, so the result of a law or constitutions are the moral law product, because according to Otong Rosadi, however the law needs moral, as the proverb in the imperial period (quid legalization legalization sine moribus), what is the meaning of constitutions without morality. ${ }^{21}$ Criminal law reform, especially in terms of setting national principle of passive should include protection for the whole nation, so a criminal law is truly reflected protection that has orientation on society protection (social defense) with an emphasis in principle balance doelmatigheid and rechtsmatigheid, it's responsibility of all the lawyers, especially for someone who work as lecturer, presence of lecturer to take responsibility of criminal law reform is said by Barda Nawawi Arief, clearly said that in order to enforcement of law and to avoid weakness/strategic mistake, who very clearly says that the enforcement and to avoid weaknesses/strategic mistake, which was also triggered by a number of weak legislative product will require thinking higher education law to come fix and think about how to improve the quality of manufacture of the constitutions. ${ }^{22}$

Contribution of ideas from lectures or law high education, will encourage the birth of cri-

20 Ibid.

21 Fence M. Wantu, "Mewujudkan Kepastian Hukum, Keadilan dan Kemanfaatan dalam Putusan Hakim di Peradilan Perdata", Jurnal Dinamika Hukum, Vol. 12 No. 3 September 2012, Purwokerto: Law Faculty of UNSOED, page 480.

22 Barda Nawawi Arief, 2008, Masalah Penegakan Hukum dan Kebijakan Hukum Pidana dalam Penanggulangan Kejahatan, Jakarta: Kencana, page 25-26. 
minal law policy better, to give birth criminal law policy better, so it's needed a comparative criminal law. Formulation of national principles that apply in the Criminal Code passive French as a comparison shows that the scope of protection that covers every citizen of France, which can be viewed at Article 113-7 of the Criminal Code of France:

French Criminal law is applicable to any felony, as well as to any misdemeanor punished by imprisonment, Committee by a French or foreign national outside the territory of the French Republic, where the victim is a French national at the time the offense took place. ${ }^{23}$

Article 113-7 of the French Code is a constitution on the protection of French citizens abroad, known as the principle of protection (national principle passive). The article asserts that "French criminal law can be applied to any crime ("felony"), as well as to each offense ("misdemeanor") which call for imprisonment, which is done by a Frenchman or foreign, if the victims were French at time that offense occurred. Therefore, protection to French in abroad based on protection principle (national principle passive) is clearly told in Criminal Code of France. This setting is very different with national protection (national passive) in Criminal Code of Indonesia, because in Criminal Code of Indonesia this setting about protection principle (national principle active) only in the law interest of country not individual, as regulated in Criminal Code of Indonesia as follows: first, crimes against state security and dignity of the president (Article 4 paragraph 1); second, the crimes of stamp or brand issued by the government (Article 4, paragraph 2); third, forgery debentures, certificates of debt at the expense of Indonesia (Article $4 \mathrm{pa}$ ragraph 3); fourth, crime positions listed in the title of the book to the second XXVIII conducted by Indonesian civil servants outside Indonesia (Article 7); and fifth, crime cruise listed in the title XXIX Book II (Article 8);

Based on that, the law interest from citizen of Indonesia (WNI) in abroad is not included
"National Interest" that is protected by national law. Individual interest protection by citizen of Indonesia in abroad (as victims of criminal law that is occurred by foreign) is all given to law that exist in the country itself. This kind of setting will put citizen of Indonesia who facing the law, in the very weak position even potential as the next victim, such as the victim when criminal law of abroad is applied to citizen of Indonesia, if like this, so clear that law criminal implementation will be a potential criminological factor. An innovation of law by criminal law politic, or criminal law policy, so the formulation of protection to Indonesia citizen, the Criminal Code concept year 2012 has been formulated a national passive principle as follows.

Determined criminal law in Indonesia Constitution is exist to all people outside Indonesia who did criminal act to: Indonesia citizen; and Indonesia state interest that has relation with: first, state security or constitutional life process; second, dignity of president, vice president, or Indonesian officials in overseas; third, forgery or impersonation brand, state seal, stamp, coin, or credit card; fourth, economy, trade, and Indonesia banking; fifth, safety or security of shipping and aviation; sixth, safety or security of buildings, equipments, and national or Indonesia state assets; seventh, safety or security of electronic communication equipment; eight, criminal act of position or corrupttion; or ninth, criminal act of money laundering.

Criminal law policy, as formulated in Article 5 of Criminal Code, will give advantages to all Indonesia citizen, so Indonesia citizen has dignity in International assessment without ignoring national law interest, and has mandated by constitution, such as welfare and protection to all Indonesia citizen and suitable with Pancasila soul.

\section{Closing}

Conclusion

23 Ridwan, "Kajian Perbandingan Dalam Rangka Pembaharuan Hukum Pidana Indonesia” Jurnal Jure Humano, Vol. 
Criminal law in general, is formulated to protecting each people from arbitrariness, included ruler arbitrariness. Criminal law is formulated to lead ruler to obey in law, not only lead society. Criminal law protection also involving in individual interest and society, so criminal law works in legal certainty, justice, and advantages to all people.

However, that legal certainty, justice and advantages, can't be felt by Indonesia citizen in abroad who facing the law, this thing is limited by formulating national passive principle at this time. Based on Criminal Code of Indonesia that still exist, national passive principle is not touch the whole Indonesia citizen interest in abroad.

\section{Suggestion}

Criminal law politic as known as criminal law policy had formulated national passive principle that can reach and protecting law interest for each Indonesia citizen in abroad. This is as innovation to achieve balance between doelmatigheid and rechtsmatigheid principle. Balance principle of both is mandate of Constitution that must be run, so welfare and protection not only word, but can be felt by all Indonesia citizen. Fulfillment of Constitution's mandate also in one track with Pancasila values. Therefore, Criminal Code of Indonesia is confirmed as ius constitutum not only ius constituendum.

\section{Bibliography}

Arief, Barda Nawawi. 2008. Bunga Rampai Kebijakan Hukum Pidana, Perkembangan Penyusunan Konsep KUHP Baru. Jakarta: Kencana;

-.-.-.. 2008. "Masalah Penegakan Hukum dan Kebijakan Hukum Pidana dalam Penanggulangan Kejahatan”. Jakarta: Kencana;

Asshidiqie, Jimly. “Judicial Review, Kajjian Atas Putusan Permohonn Hak Uji Materil Terhadap PP No. 19 Tahun 2000 Tentang TGPTPK". Dictum Journal, $1^{\text {st }}$ Edition, 2002. Jakarta: LeIP;

Din, Mohd. "Restoratif Justice dalam Wawasan Pemidanaan Menurut Hukum Adat Gayo". Jurnal Kanun, Vol. IIX No. 50 April 2010. Banda Aceh: Law Faculty of Syiah Kuala University;
Hemansyah, Adi. "Penanggulngan Kejahatan dengan Pidana Badan di Indonesia." Jurnal Kanun. Vol. XV No. 60 August 2013. Banda Aceh: Law Faculty of Syiah Kuala University;

Nuraini, Fera. Kartika Ajukan Banding Kasus Penyiksaannya. Migrant Workers Resource Center, available at website http://www. buruhmigran.or.id/2014/05/27/kartikaajukan-banding-kasus-penyiksaannya/, accessed on $4^{\text {th }}$ August 2014.;

Prakarsa, Aliyt. "Tanggung Jawab Dunia Akademik dalam Upaya Perlindungan Korban". Jurnal Jure Humano. Vol. 1 No. 1 March 2009. Serang: Law Faculty of Sultan Ageng Tirtayasa University;

Purnomo, Langgeng. "Kesepakatan Sosial sebagai Upaya Pencegahan dan Penanggulangan Tindak Pidana Pemilu (studi Kasus Konflik Pemilu Tahun 2004 di Kabupaten Batang)". Jurnal Pembaharuan Hukum, Vol. 3 No.1 February 2007. Semarang: Law Master Program Degree of UNDIP;

Ridwan. "Menelaah Kembali Penerapan hukum Represif dalam Penegakan Hukum Pidana di Indonesia”, Jurnal Litigasi, Vol. 10 No. 2 June 2009. Bandung: Law Faculty of Unpas;

-..-..-. "Relevansi, Restorative Justice dalam Penanganan Anak Delinquen". Jurnal Jure Humano, Vol. 1 No. 3 November 2009. Serang: Law Faculty of Sultan Ageng Tirtayasa University;

-..-..-. “Upaya Penanggulangan Terorisme yang Berkarakter Hak Asasi Manusia di Indonesia". Jurnal Media Hukum, Vol. 17 No. 1 June 2010. Yogyakarta: Law Faculty of UMY;

-.-.-.. "Kajian Perbandingan dalam Rangka Pembaharuan Hukum Pidana Indonesia". Jurnal Jure Humano, Vol. 2 No. 3 July 2010. Serang: Law Faculty of Sultan Ageng Tirtayasa University;

.....-. "Upaya Memperbaharui Sistem Hukum Guna Membangun Integritas Penegak Hukum”. Jurnal Konstitusi PKK, Vol. II No.1 June 2011. Lombok: Law Faculty of UNRAM;

. "Meneropong Efektifitas Sistem Pemidanaan di Indonesia". Jurnal Jure Humano, Vol. 3 No. 6 April 2012. Serang: Law Faculty of Sultan Ageng Tirtayasa University;

-.-.-.-. "Kebijakan Formulasi Hukum Pidana dalam Penanggulangan Tindak Pidana Korup- 
192 Jurnal Dinamika Hukum Vol. 15 No. 2, May 2015

si". Jurnal Kanun, Vol. XV No. 60 August 2013. Banda Aceh: Law Faculty of Syiah Kuala University;Sodikin. "Dinamika Politik Hukum Hak Asasi Ma-nusia". Jurnal Konstitusi PKK, Vol. II No.1 June 2011. Lombok: Law Faculty of UNRAM;

Soetedjo, Wagiati. "Perlindungan Hukum Terhadap Anak dalam Hukum Pidana di Indonesia". Ligitation Journal, Vol. 10 No. 2 June 2009. Bandung: Law Faculty of Unpas;

Wantu, Fence M. "Mewujudkan Kepastian Hukum, Keadilan dan Kemanfaatan dalam Putusan Hakim di Peradilan Perdata". Law Media Journal. Vol. 12 No. 3 September 2012. Edition. Purwokerto: Law Faculty of Unsoed;

Yusrizal. 2012."Tanggung Jawab Korporasi Terhadap Korban Kejahatan Tindak Pidana Lingkungan Hidup". Jurnal Kanun, Vol. XIV No. 57 August Edition. Banda Aceh: Law Faculty of Syiah Kuala University. 
Critical Study to the Enforceability of Passive National Principle in Indonesia Criminal Code 193 